\title{
Does Addition of Phosphate and Ammonium Nutrients Affect Microbial Activity in Froth Treatment Affected Tailings?
}

\author{
Juliana A. Ramsay *, Mara R. de Lima e Silva, Michael A. R. Tawadrous and Bruce A. Ramsay \\ Chemical Engineering, Queen's University, Kingston, ON K7L 3N6, Canada; \\ mara.silva@queensu.ca (M.R.d.L.eS.); michael.tawadrous@queensu.ca (M.A.R.T.); \\ bruce.ramsay@queensu.ca (B.A.R.) \\ * Correspondence: juliana.ramsay@queensu.ca; Tel.: +1-613-533-2770
}

check for

updates

Citation: Ramsay, J.A.; de Lima e Silva, M.R.; Tawadrous, M.A.R.;

Ramsay, B.A. Does Addition of

Phosphate and Ammonium Nutrients

Affect Microbial Activity in Froth

Treatment Affected

Tailings? Microorganisms 2021, 9, 2224.

https://doi.org/10.3390/

microorganisms 9112224

Academic Editors: Julia M. Foght and Tariq Siddique

Received: 22 September 2021

Accepted: 22 October 2021

Published: 26 October 2021

Publisher's Note: MDPI stays neutral with regard to jurisdictional claims in published maps and institutional affiliations.

Copyright: (C) 2021 by the authors. Licensee MDPI, Basel, Switzerland. This article is an open access article distributed under the terms and conditions of the Creative Commons Attribution (CC BY) license (https:/ / creativecommons.org/licenses/by/ $4.0 /)$.

\begin{abstract}
We examined greenhouse gas (GHG) production upon the addition of ammonium and phosphate to mature fine tailing (MFT) samples from Alberta's Pond 2/3 (at 5 and $15 \mathrm{~m}$ ) and Pond 7 $(12.5 \mathrm{~m}$ ) in microcosm studies. The methane production rate in unamended Pond 2/3 MFT correlated with sample age; the production rate was higher in the less dense, more recently discharged MFT samples and lower in the denser, deeper sample. Adding small amounts of naphtha increased methane production, but there was no correlation with increasing naphtha, indicating that naphtha may partition into bitumen, reducing its bioavailability. Although non-detectable phosphate and low ammonium in the pore water indicate that these nutrients were potentially limiting microbial activity, their addition did not significantly affect methanogenesis but somewhat enhanced sulphate and nitrate reduction. Neither ammonium nor phosphate were detected in the pore water when added at low concentrations, but when added at high concentrations, 25-35\% phosphate and 30-45\% ammonium were lost. These ions likely sorbed to MFT minerals such as kaolinite, which have microbial activity governed by phosphate/ammonium desorption. Hence, multiple limitations affected microbial activity. Sulphate was less effective than nitrate was in inhibiting methanogenesis because $\mathrm{H}_{2} \mathrm{~S}$ may be a less effective inhibitor than $\mathrm{NO}_{x}{ }^{-}$intermediates are, and/or $\mathrm{H}_{2} \mathrm{~S}$ may be more easily abiotically removed. With nitrate reduction, $\mathrm{N}_{2} \mathrm{O}$, a potent $\mathrm{GHG}$ was produced but eventually metabolized.
\end{abstract}

Keywords: oilsands tailing ponds; mature fine tailings; ammonium; phosphate; microbial activity

\section{Introduction}

In 2021, Canada was ranked as having the 4th largest global crude oil reserves, amount to about 170,300 million barrels [1], and in 2020, it was the 4th largest global oil producer, producing 5.5 million barrels per day [2]. About 55\% of Canada's crude oil production is from Alberta's oil sands. There are three major deposits (Peace River, Athabasca, and Cold Lake), which cover $142,200 \mathrm{~km}^{2}$, where $\sim 3 \%$ can be surface mined [3], and this represents $\sim 20 \%$ of Alberta's oil sand reserves. The oil sand ore consists of $12 \%$ bitumen, $3-6 \%$ water, and the is rest mineral ore. Bitumen is separated from the ore through the Clark hot water process as an initial separation step. The oil recovered by flotation is subsequently purified by adding a hydrocarbon diluent (e.g., naphtha or paraffinic solvents) and by separating the remaining water and solids from the bitumen froth. The froth treatment tailings (FTT) are discarded to an oil sand tailings pond (OSTP). Although a majority of the diluent and bitumen are recovered, about $16 \mathrm{wt} \%$ solids, $1-2 \mathrm{wt} \%$ bitumen, and $0.2 \mathrm{wt} \%$ diluent (Per. Comm. E. Hollander, Suncor) [4] are discharged with the process water to the OSTP. With time, the tailings consolidate to form a dense suspension called mature fine tailings (MFT), where the older tailings at the bottom have a higher density of solids. The composition of the naphtha diluent varies with each company and includes low molecular weight C5 to C16 n-, iso-, and cyclo-alkanes as well as aromatic hydrocarbons such as benzene, toluene, ethylebenzene, and xylene (BTEX). OSTPs that receive FTT containing naphtha diluent 
typically have higher greenhouse gas (GHG) emissions such as $\mathrm{CH}_{4}$ and $\mathrm{CO}_{2}$, which arise from the microbial degradation of the biodegradable components of naphtha and bitumen under methanogenic conditions. Since $\mathrm{CH}_{4}$ has a global warming potential that is $28-36$ times greater than $\mathrm{CO}_{2}$ over 100 years [5], understanding the factors that influence GHG production in OSTPs is important to develop strategies to minimize GHG production.

In most laboratory studies looking at GHG production, MFT samples were spiked with diluent or hydrocarbons and were frequently amended with a methanogenic medium such as the one used by Fedorak and Hrudey [6] and others [7-14] containing mineral salts such as $\mathrm{NH}_{4} \mathrm{Cl}, \mathrm{KH}_{2} \mathrm{PO}_{4}$, and trace elements as well as vitamins. Although nutrients such as a nitrogen and/or phosphorous source can influence degradation rates, there have been no studies that have examined the impact of $\mathrm{NH}_{4}{ }^{+}$and /or $\mathrm{PO}_{4}{ }^{3-}$ substrates on GHG production by the microbial population in MFT or examined potential interactions of $\mathrm{NH}_{4}{ }^{+}$and/or $\mathrm{PO}_{4}{ }^{3-}$ with the minerals in MFT. There are many studies that have looked at the impact of $\mathrm{NH}_{4}{ }^{+}$and $\mathrm{PO}_{4}{ }^{3-}$ on microbial activity, including hydrocarbon degradation activity, but we found very few specific to OSTPs or MFT. In one study, Collins et al. [15] found that an enrichment culture from an Albian MFT was able to fix nitrogen under methanogenic conditions, and this suggests that an ammonium source may not be needed. However, it is not known how such cultures fit into the MFT population. Furthermore, while there are many studies that have examined the interaction of $\mathrm{NH}_{4}{ }^{+}$or $\mathrm{PO}_{4}{ }^{3-}$ in different soils and soil components, we once again did not find any published studies with respect to MFT. In this paper, we examined GHG production in unamended MFT samples, the impact of adding $\mathrm{NH}_{4}{ }^{+}$and $\mathrm{PO}_{4}{ }^{3-}$ on GHG production under methanogenic, sulphate- and nitrate-reducing conditions, and the possible fate of that $\mathrm{NH}_{4}{ }^{+}$and $\mathrm{PO}_{4}{ }^{3-}$. Three MFT samples were used: Suncor's Pond $2 / 3$ at 5 and $15 \mathrm{~m}$ and Pond 7 at $12.5 \mathrm{~m}$. FTT is discharged to Pond $2 / 3$, from which some MFT is transferred to Pond 7 for inventory management purposes. The water surface areas of Pond $2 / 3$ and Pond 7 are 2.8 and $3.9 \mathrm{~km}^{2}$, respectively.

\section{Materials and Methods}

\subsection{Chemicals}

Monopotassium phosphate $\left(\mathrm{KH}_{2} \mathrm{PO}_{4}\right)$ was obtained from Anachemia Chemicals Inc., Lachine, $\mathrm{PQ}$, Canada, ammonium chloride $\left(\mathrm{NH}_{4} \mathrm{Cl}\right)$ was obtained from Fisher Scientific, Toronto, ON, Canada and naphtha was obtained from (Suncor Energy Inc., Edmonton, AB, Canada).

\subsection{Description of MFT, Its Collection and Storage}

The MFT samples were taken from Suncor's Pond 2/3 at depths of $5 \mathrm{~m}$ and $15 \mathrm{~m}$ on 12 September 2018 as well as from Pond 7 at a depth $12.5 \mathrm{~m}$ on 10 September 2018. Tailings were stored in $20 \mathrm{~L}$ tightly sealed, high density polyethylene pails. Once the pails were received on 18 September 2018 , the contents were stored at $2{ }^{\circ} \mathrm{C}$ until use.

\subsection{Microcosm Set Up}

Microcosms were set up in duplicate. Prior to use, the MFT was left at room temperature for about $24 \mathrm{~h}$. To $60 \mathrm{~mL}$ of MFT in $125 \mathrm{~mL}$ microcosm bottles, $20 \mathrm{~mL}$ of sterile deionized water (unamended biotic controls) or $20 \mathrm{~mL}$ of sterile deionized water containing the appropriate concentration of phosphate and/or ammonium solution were added to a final liquid volume of $80 \mathrm{~mL}$ and a headspace of $45 \mathrm{~mL}$. Microcosms were sealed with a butyl rubber stopper and an aluminum crimp (Fisher Scientific, Toronto, ON, Canada). The headspace was purged with ultra-high purity nitrogen gas (Praxair Canada Inc., Kingston, ON, Canada) for 30 min using a manifold system in the fume hood, according to the Hungate technique [16]. After purging, a slight positive pressure was maintained in each microcosm, and the initial pressure was measured, and the naphtha added. The surface of the butyl rubber stopper was made leak-tight by applying a few drops of $70 \% v / v$ ethanol and then burning off the alcohol. The contents of the microcosms were mixed in an orbital 
rotary incubator (Innova 44 series, New Brunswick Scientific, Enfield, CT, USA) at 200 rpm for 30-60 min; the mixing was repeated after every gas analysis, and the microcosms were incubated statically in the dark at room temperature $\left(20^{\circ} \mathrm{C}\right)$.

Abiotic controls were created by autoclaving the MFT with nutrient amendments as appropriate (not including naphtha) once per day for three consecutive days at $121{ }^{\circ} \mathrm{C}$ for 20 min [9] before sealing with butyl rubber stopper, purging with $\mathrm{N}_{2}$ gas, and adding naphtha.

\subsection{Gas Analysis}

The gas phase was analyzed using an Agilent 7890B gas chromatograph with a $1 \mathrm{~mL}$ fixed loop splitless injector connected to a PoraBOND Q column (50 m long, 0.53 $\mathrm{mm}$ diameter, and a $10 \mu \mathrm{m}$ thick film, Agilent) and to an Agilent thermal conductivity detector. The pressure in the microcosms was measured with a digital pressure gauge (SSI Technologies, Inc., Janesville, WI, USA) prior to taking $5 \mathrm{~mL}$ of the headspace gas with a gas-tight Hamilton syringe attached to an $0.2 \mu \mathrm{m}$ nylon syringe filter ( $25 \mathrm{~mm}$ diameter). Before sampling, the syringe and filter were flushed with $\mathrm{N}_{2}$ gas several times. After sampling the microcosm, a few drops of alcohol were placed on the septum and were flamed to seal any leaks. Dilutions of a calibration mixture of $6.5 \%$ carbon dioxide and 6.5\% methane in nitrogen (Praxair Canada Inc.) was used to generate calibration curves, and the concentrations of $\mathrm{CH}_{4}$ and $\mathrm{CO}_{2}(\mu \mathrm{mol} / 100 \mathrm{~mL} \mathrm{MFT})$ were corrected for volume and headspace pressure.

\subsection{Pore Water Analysis \\ 2.5.1. $\mathrm{pH}$ and Eh}

Initial $\mathrm{pH}$ and Eh values were measured in sacrificial $\mathrm{t}=0$ microcosms. Once the experiments terminated, the final $\mathrm{pH}$ and Eh were measured in an anaerobic chamber (Nexus One Glove Box, Vacuum Atmospheres Company, Topsfield, MA, USA) using a pH electrode (LE409, Mettler Toledo, Columbus, OH, USA) and an Eh electrode (ORP InLab Redox Flow, Mettler Toledo, Columbus, OH, UAS) connected to a Mettler Toledo SevenEasy $\mathrm{pH}$ meter. An Orion ${ }^{\mathrm{TM}}$ ORP standard solution (Thermo Scientific, Toronto, ON, Canada) of Eh $\sim 236 \pm 6 \mathrm{mV}$ was used to calibrate the ORP electrode.

\subsubsection{Water Chemistry}

The pore water was collected from $30 \mathrm{~mL}$ of relatively homogenous MFT microcosm samples and was placed into $50 \mathrm{~mL}$ conical polypropylene centrifuge tubes (Fisher Scientific) and centrifuged at $8000 \mathrm{rev} / \mathrm{min}$ for $45 \mathrm{~min}$ [7] at $8{ }^{\circ} \mathrm{C}$ using a Sorvall RC-5B centrifuge. The recovered pore water samples were filtered to remove the oil phase, and any suspended fines were removed using a $5 \mathrm{~mL}$ gas-tight syringe (Model 1005, Hamilton Company, Reno, NV, USA) attached to a nylon syringe filter $(0.2 \mu \mathrm{m}$ pore size, $25 \mathrm{~mm}$ diameter, VWR, Toronto, ON, Canada).

Phosphate, sulphate, and nitrate were measured by the Analytical Services Unit, Queen's University, using a Dionex HPLC system (ICS-3000) equipped with a Dionex AG4A-SC guard column and an AS4A-SC analytical column connected to a conductivity detector operated in a suppressed conductivity mode. A calibration curve of standards, which ranged from 0.08 to $50 \mathrm{mg} / \mathrm{L}$, was used to quantify concentrations. Ammonium was determined by a colorimetric assay using a continuous flow AutoAnalyzer (QuAAtro AutoAnalyzer, SEAL Analytical, Inc., Mequon, WI, USA) in which the ammonium reacted with Berthelot's reagent, which is an alkaline solution of phenoxide and sodium hypochlorite. The addition of sodium nitroprusside intensified the color, which was measured colorimetrically at $630 \mathrm{~nm}$ [17].

\subsection{Total Dried Solids}

The amount of MFT solids was measured according to Symons and Morey [18]. Each $20 \mathrm{~L}$ pail was mixed on a drive roll mixer (2" diameter, $24^{\prime \prime}$ long, 2-roll, Sepor Inc., Los 
Angeles, CA, USA) for $2 \mathrm{~h}$. A volume of $16 \mathrm{~mL}$ of MFT was pumped from each bucket (Pond 7 and Pond $2 / 3$ at $5 \mathrm{~m}$ or $15 \mathrm{~m}$ ) and was placed on pre-weighed, clean, dry glass Petri dishes and dried at $105^{\circ} \mathrm{C}$ overnight. The Petri dishes plus sample were cooled in a desiccator before re-weighing to constant weight.

\subsection{X-ray Diffraction}

Ammonium and phosphate were mixed with MFT for $30 \mathrm{~min}$ and were then left to equilibrate at room temperature for $24 \mathrm{~h}$. About $10 \mathrm{~g}$ of this mixture was placed on a glass Petri dish and was allowed to dry in the fume hood for $24 \mathrm{~h}$. The samples were disaggregated with a mortar and pestle before $\sim 5 \mathrm{~g}$ were analyzed by $\mathrm{X}$-ray diffraction (XRD). XRD was performed with an X-ray diffractometer (X'Pert Pro MPD, PANalytical, Henderson, NV, USA) with Co-K $\alpha$ radiation (1.78 $\AA$ ) operating at $40 \mathrm{kV}$ and $45 \mathrm{~mA}$. The $2 \theta$ angle was varied from $5^{\circ}$ to $90^{\circ}$ with a scan $X^{\prime}$ Celerator detector of $90 \mathrm{~s} / \mathrm{step}$.

\section{Results and Discussion}

\subsection{Characterization of MFT}

Pond $7(12.5 \mathrm{~m})$ had the lowest amount of total dried solids followed by Pond $2 / 3$ at $5 \mathrm{~m}$ and then Pond $2 / 3$ at $15 \mathrm{~m}$ (Table 1). This reflects the relative age of the MFT samples since discharge. Because the amount of solids increases with the settling time, it can be inferred that the Pond 7 MFT samples had the shortest consolidation times and that the $15 \mathrm{~m}$ depth samples from Pond $2 / 3$ had the longest consolidation times. Pond $2 / 3$ had higher levels of ammonium and sulphate at $15 \mathrm{~m}(35.3$ and $100 \mathrm{mg} / \mathrm{L}$, respectively) than at $5 \mathrm{~m}(20.8$ and $20 \mathrm{mg} / \mathrm{L}$, respectively), while Pond 7 had no detectable sulphate and a much lower level of ammonium $(6.4 \mathrm{mg} / \mathrm{L})$. No detectable amounts of phosphate, nitrate, or nitrite (Table 1) were found in the pore water of any pond sample. The lack of detectable phosphate suggests that biodegradation rates may be limited by phosphate availability. Low ammonium levels may also play a role. These data support the need to understand the effect of $\mathrm{PO}_{4}{ }^{-3}$ and $/$ or $\mathrm{NH}_{4}{ }^{+}$on the microbial activity in MFT samples.

Table 1. Characterization of three MFT samples. ${ }^{\text {a }}$ Per. Comm. E. Hollander, Suncor [4].

\begin{tabular}{|c|c|c|c|}
\hline Parameter & Pond $2 / 3$ at $5 \mathrm{~m}$ & Pond $2 / 3$ at $15 \mathrm{~m}$ & Pond 7 at $12.5 \mathrm{~m}$ \\
\hline $\mathrm{PO}_{4}^{3-}(\mathrm{mg} / \mathrm{L})$ & $<3.1$ & $<3.1$ & $<3.1$ \\
\hline $\mathrm{NH}_{4}^{+}(\mathrm{mg} / \mathrm{L})$ & $20.8 \pm 0.5$ & $35.5 \pm 0.7$ & $6.4 \pm 2.4$ \\
\hline $\mathrm{SO}_{4}^{2-}(\mathrm{mg} / \mathrm{L})$ & 20 & 100 & $<1.0$ \\
\hline $\mathrm{NO}_{3}^{-}(\mathrm{mg} / \mathrm{L})$ & $<0.5$ & $<0.5$ & $<0.5$ \\
\hline $\mathrm{NO}_{2}^{-}(\mathrm{mg} / \mathrm{L})$ & $<0.33$ & $<0.33$ & $<0.33$ \\
\hline Eh $(\mathrm{mV})$ & -123 & -153 & $-200 \pm 40$ \\
\hline Naphthenic Acid $(\mu \mathrm{g} / \mathrm{L})^{\mathrm{a}}$ & 15,100 & 54,700 & 27,600 \\
\hline $\mathrm{pH}$ & $8.41 \pm 0.1$ & $8.39 \pm 0.1$ & $8.11 \pm 0.4$ \\
\hline Alkalinity, Bicarbonate $(\mathrm{mg} / \mathrm{L})^{a}$ & 2100 & 1900 & 1900 \\
\hline $\mathrm{DOC}(\mathrm{mg} / \mathrm{L})^{\mathrm{a}}$ & 56 & 24 & 46 \\
\hline Hardness $\left(\mathrm{mg} \mathrm{CaCO}_{3} / \mathrm{L}\right)^{a}$ & 240 & 180 & 160 \\
\hline Total dried solids $(\mathrm{g} / \mathrm{L})$ & $743 \pm 11.47$ & $1000 \pm 3.30$ & $415 \pm 4.77$ \\
\hline
\end{tabular}

\subsection{Methanogenic Metabolism}

Amended or unamended abiotic controls had no biological activity, i.e., no detectable methane production. Unamended biotic controls (i.e., no additives) had low but statistically significant biological activity, which was determined using one-way ANOVA with Dunn's post hoc test ( $p<0.005$ for any unamended sample vs. abiotic control). Figure 1A shows a plot of two independent experiments performed in duplicate for each MFT sample 
incubated in the dark without amendments. The average rate of $\mathrm{CH}_{4}$ production for each sample (Table 2) represents baseline conditions in the tailing ponds, which were all methanogenic, even though Pond $2 / 3$ at $5 \mathrm{~m}$ and at $15 \mathrm{~m}$ had 20 and $100 \mathrm{mg} / \mathrm{L}$ of sulphate, respectively. Methane production has been previously reported with $\leq 20 \mathrm{mg} / \mathrm{L}$ sulphate in MFT from the Mildred Lake Settling Basin [7]. Methanogens and sulphate reducers can co-exist and compete for resources, although sulphate reducers have a thermodynamic advantage compared to methanogens when using most electron donors, with the exception of when they are used with acetate. Thus, acetotrophic methanogens can be very active in the presence of sulphate [19]. Some studies [20,21] have shown that sulphate-induced inhibition of methanogenesis is associated with the ratio of grams of organic carbon (COD) that the microorganisms can oxidize to grams of sulphate. At low sulphate, when the $\mathrm{COD} /$ sulphate ratio is $>10$, sulphate reduction is minimal, and methanogenesis is unaffected [20], while at COD/sulphate ratios $<1$, the sulphate reducers can outcompete the methanogens [21]. Hence, the COD to sulphate ratio in our studies was likely $>10$.

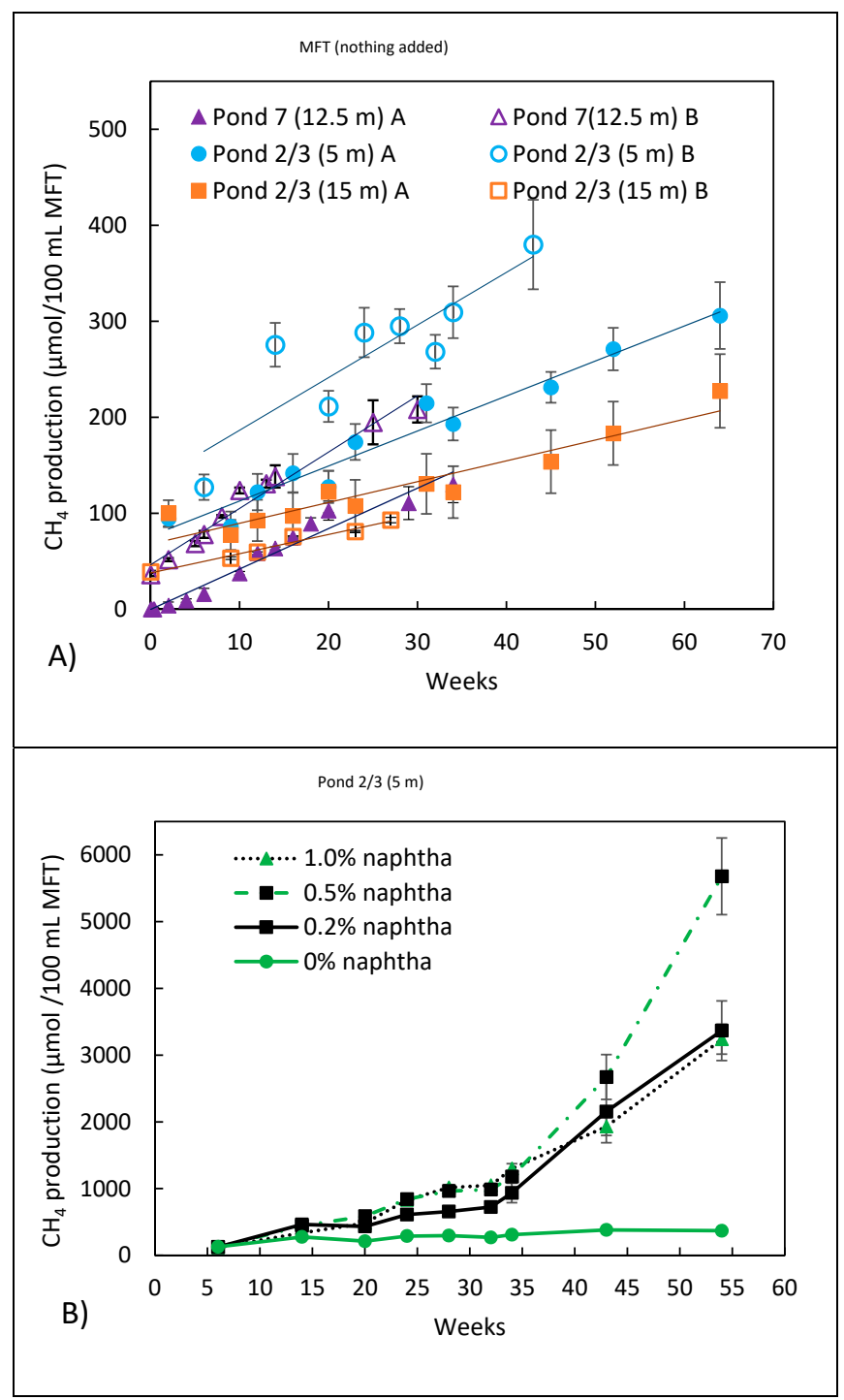

Figure 1. (A) Methane production of duplicate microcosms for each MFT sample in two independent experiments, each performed in duplicate. No amendments were added. The solid line represents the average rate of methane production for each pond sample as baseline conditions. (B) Methane production from duplicate MFT samples from Pond 2/3 at $5 \mathrm{~m}$ when naphtha alone was added. After naphtha addition, microcosms were mixed for 30-60 min on a rotary shaker then incubated in the dark. Error bars have been inserted, and where not visible, the error was too small to be seen. 
Table 2. Methanogenic rates in unamended (i.e., nothing added) MFT microcosms calculated using the data from Figure 1A. Values are the average of at least two measurements, except for *, which is a single analysis or NM (not measured).

\begin{tabular}{|c|c|c|c|c|c|}
\hline \multirow{2}{*}{$\begin{array}{l}\text { Unamended MFT } \\
\text { (Nothing Added) }\end{array}$} & \multicolumn{2}{|c|}{$\mathrm{pH}$} & \multicolumn{2}{|c|}{ Redox (mV) } & \multirow{2}{*}{$\begin{array}{c}\mathrm{CH}_{4} \text { Generation Rate } \\
(\mu \mathrm{mole} / 100 \mathrm{~mL} \text { MFT/Day) }\end{array}$} \\
\hline & Initial & Final & Initial & Final & \\
\hline Pond 7 at $12.5 \mathrm{~m}$ & $7.89 \pm 0.1$ & $7.82 \pm 0.1$ & $-136 \pm 11$ & $-247 \pm 4$ & $0.72 \pm 0.12$ \\
\hline Pond $2 / 3$ at $5 \mathrm{~m}$ & $7.13 \pm 0.3$ & $7.84 \pm 0.1$ & $-120 \pm 2$ & $-129 \pm 12$ & $0.56 \pm 0.04$ \\
\hline Pond $2 / 3$ at $15 \mathrm{~m}$ & $7.39 *$ & $\mathrm{NM}$ & $-155^{*}$ & $\mathrm{NM}$ & $0.30 \pm 0.01$ \\
\hline
\end{tabular}

The "intrinsic" methanogenic activity (Figure 1A and Table 2) was the highest with the MFT of Pond 7, followed by Pond 2/3 (5 m) and then Pond 2/3 (15 m). The order of the two MFT samples from Pond 2/3 correlates with the age of the tailings, with the higher rate occurring with the less dense, i.e., younger, MFT and the lower rate with the older, deeper MFT. A similar trend was found by Siddique et al. [22] with unamended MFT from a different OSTP, the Mildred Lake Settling Basin (MLSB), in which a sample taken at $6 \mathrm{~m}$ produced more methane than a sample taken at $31 \mathrm{~m}$. The "age" of the material can reflect differences such as the microbial population and chemical composition.

Naptha $(0.2$ to $1.0 \% \mathrm{wt} / \mathrm{vol})$ was added to the MFT samples under methanogenic conditions at concentrations consistent with those discharged into the tailing ponds (Small et al. 2015) [23]. No other ammendments were added. The results for the MFT of Pond $2 / 3(5 \mathrm{~m}$ ) (Figure 1B) were similar in all of the pond samples. With the addition of $0.2 \%$ (wt/vol) naphtha, $\mathrm{CH}_{4}$ production increased above the "intrinsic" rate (Figure 1B; note the difference in $y$-axis scale on Figure $1 \mathrm{~A}, \mathrm{~B})$. However, adding more naphtha (0.5 and $1.0 \%(\mathrm{wt} / \mathrm{vol}))$ did not substantially increase methane production. There appeared to be an initial lag phase, with a rate of about $4.6 \pm 1.4 \mu$ mole $\mathrm{CH}_{4}$ per $100 \mathrm{~mL}$ of MFT per day in the first 32 days followed by a higher rate of $\sim 20.5 \pm 2.5 \mu$ mole $\mathrm{CH}_{4}$ per $100 \mathrm{~mL}$ of MFT per day. However, we believe that the slower rate was not a true lag phase since nitrate-reducing and sulphate-reducing activities were typically evident within 5 days (Figures 4 and 5), and these samples were already methanogenic, as seen in Figure 1A. The change from the slower to the faster rate of methane production may be due to a shift in the metabolism from acetotrophic to hydrogenotrophic methanogens. Acetotrophic methanogens use acetate fermentatively as the electron donor and electron acceptor $\left(\mathrm{CH}_{3} \mathrm{COOH} \rightarrow \mathrm{CH}_{4}\right.$ $+\mathrm{CO}_{2}$ ) [24], so they derive less energy, and their growth and methane production rates are slower. On the other hand, hydrogenotrophic methanogens use $\mathrm{CO}_{2}$ as the electron acceptor and $\mathrm{H}_{2}$ as the electron donor $\left(\mathrm{CO}_{2}+4 \mathrm{H}_{2} \rightarrow \mathrm{CH}_{4}+2 \mathrm{H}_{2} \mathrm{O}\right)$ [24] to generate more energy, resulting in higher growth and methane production rates.

The rate of methane production should have increased with increasing naphtha concentration if the cultures were carbon-limited. Several studies $[7,10,11,25]$ that have added 1:1 MFT to a methanogenic medium have found that the rate of methane production approximated to the first order with respect to diluent components. Since we found no correlation with the amount of naphtha, one possible explanation is that nutrients such as a $\mathrm{NH}_{4}{ }^{+}$or $\mathrm{PO}_{4}{ }^{3-}$ may limit the rate of methane production when the naphtha increases, especially since phosphate was below detectable levels and ammonium was low in the "as received" pore water from the MFT samples (Table 1).

To assess the effect of ammonium and phosphate in a reasonable timeframe, a small amount of naphtha $(0.2 \% \mathrm{wt} / \mathrm{vol})$ was added to enhance methanogenic activity. High ammonium and phosphate concentrations were based on the methanogenic medium of Fedorak and Hrudey [6], and low concentrations were based on Takashima and Speece [26] for the minimum requirements for methanogenesis. The results in Figure 2 for the Pond 2/3 $(15 \mathrm{~m})$ MFTs are representative of all of the pond samples. With the addition of $0.2 \%$ naptha alone (biotic control), methane production was significantly higher than when nothing was added (Figure 2A,C) using one-way ANOVA with Dunn's post hoc test $(p<0.05)$. However, adding $\mathrm{NH}_{4}{ }^{+}$or $\mathrm{PO}_{4}{ }^{3-}$ alone or in combination at low $\left(57.5 \mathrm{mg} / \mathrm{mL} \mathrm{NH}_{4}{ }^{+}\right.$ 
and $\left.44.7 \mathrm{mg} / \mathrm{L} \mathrm{PO}_{4}{ }^{3-}\right)$ or high $\left(720 \mathrm{mg} / \mathrm{mL} \mathrm{NH}_{4}{ }^{+}\right.$and $\left.1606 \mathrm{mg} / \mathrm{L} \mathrm{PO}_{4}{ }^{3-}\right)$ concentrations resulted in similar methane production as when only naphtha was added. $\mathrm{CO}_{2}$ production at the lower concentration of $\mathrm{NH}_{4}{ }^{+}$and $\mathrm{PO}_{4}{ }^{3-}$ followed a similar trend to $\mathrm{CH}_{4}$ (Figure 2B). The higher $\mathrm{CO}_{2}$ measured at $\mathrm{t}=0$ when nutrient levels were higher (Figure 2B,D) clearly indicates that abiotic processes were involved. For example, upon the addition of 286 or $1404 \mathrm{mg} / \mathrm{L} \mathrm{PO}_{4}{ }^{3-}$ to Pond $7 \mathrm{MFT}$, the $\mathrm{pH}$ decreased from 7.95 to 7.30 and 7.03, respectively. This change in $\mathrm{pH}$ would have shifted the $\mathrm{CO}_{2}$ equilibrium between what is dissolved in water, what is present in the gas phase, and what is trapped as bicarbonate $(\sim 1900 \mathrm{mg} / \mathrm{L})$ to release abiotic $\mathrm{CO}_{2}$. Over time, the equilbrium can be further affected by biologically produced and biologically consumed $\mathrm{CO}_{2}$, making the interpretation of the $\mathrm{CO}_{2}$ data difficult with any $\mathrm{pH}$ change.
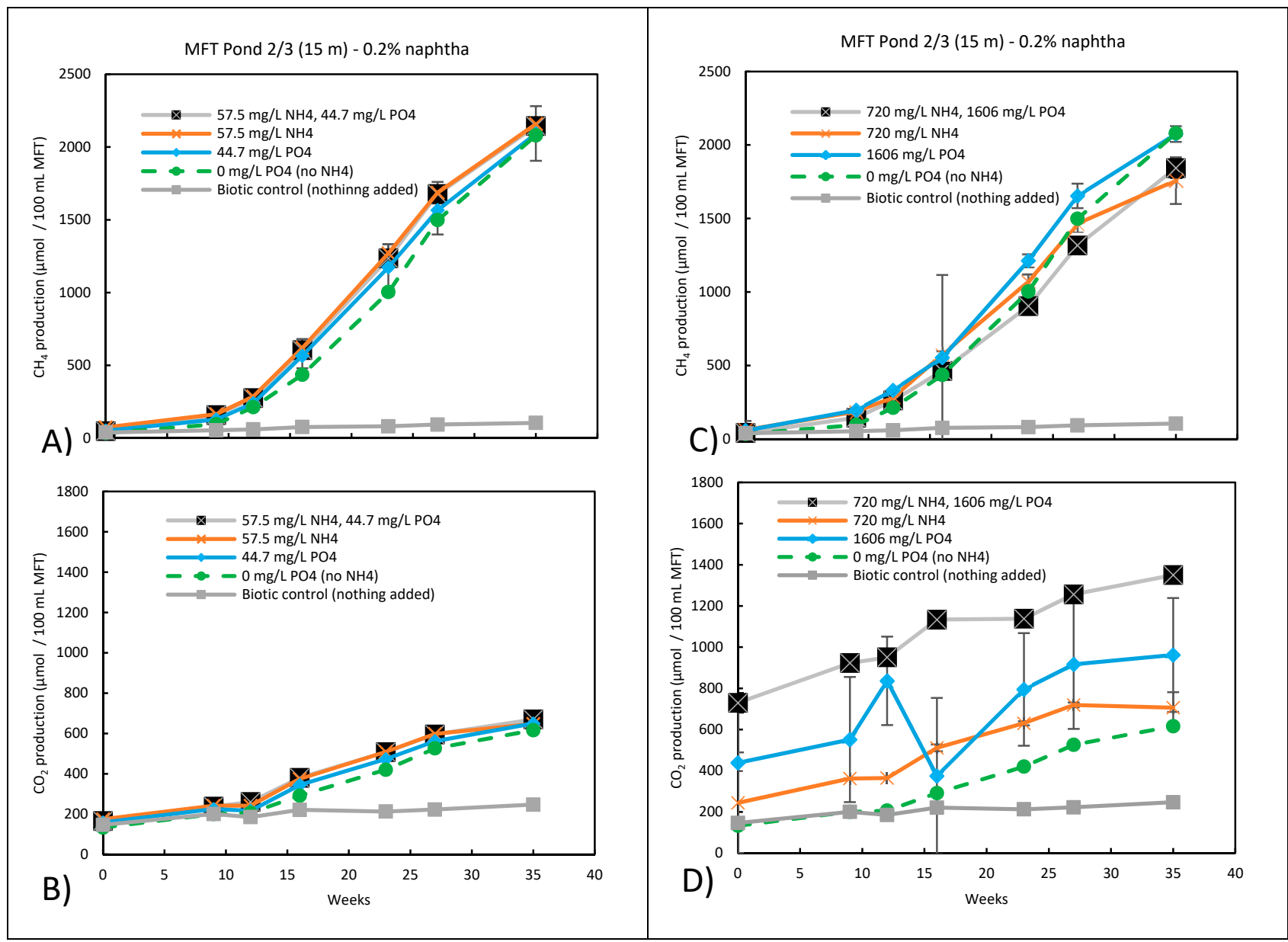

Figure 2. (A) $\mathrm{CH}_{4}$ and (B) $\mathrm{CO}_{2}$ production of duplicate microcosms for MFT from Pond $2 / 3$ at $15 \mathrm{~m}$ amended with $0.2 \%$ naphtha and low concentrations of $\mathrm{NH}_{4}{ }^{+}$and /or $\mathrm{PO}_{4}{ }^{3-}$. (C) $\mathrm{CH}_{4}$ and (D) $\mathrm{CO}_{2}$ production of duplicate microcosms for MFT from Pond 2/3 at $15 \mathrm{~m}$ amended with $0.2 \%$ naphtha and high concentrations of $\mathrm{NH}_{4}{ }^{+}$and $/$or $\mathrm{PO}_{4}{ }^{3-}$. After naphtha addition, microcosms were mixed for 30-60 min on a rotary shaker then incubated in the dark. Error bars have been inserted, and where not visible, the error was too small to be seen.

\subsection{Sulfidogenic Metabolism}

Sulfidogenic conditions were created by adding 1062 and $2500 \mathrm{mg} / \mathrm{L} \mathrm{of} \mathrm{SO}_{4}{ }^{2-}$ to MFT from Pond $7(12.5 \mathrm{~m})$ and Pond 2/3 $(5 \mathrm{~m})$, respectively, and sulphate reduction was confirmed by $\mathrm{H}_{2} \mathrm{~S}$ production in the gas phase (Figure $3 \mathrm{~A}, \mathrm{C}$ ). We relied on gas instead of pore water analysis to routinely track microbial activity as frequent water phase analyses were not practical because they required a large sample volume due to the high solid content. In the Pond 7 MFT, methane production was inhibited, and there was an increase in sul- 
phate reduction with the addition of ammonium and phosphate compared to ammonium alone, but sulphate reduction did not increase with increasing phosphate concentration (Figure $3 \mathrm{~A}, \mathrm{~B}$ ). It was only with sulphate and no ammonium nor phosphate added to the MFT of Pond 2/3 (5 m) that methane production was inhibited, and sulphate-reducing activity was evident with a small amount of $\mathrm{H}_{2} \mathrm{~S}$ production at day 5 (Figure 3C,D). With the addition of ammonium and phosphate, sulphate reduction was somewhat enhanced. Although the experiments were set up slightly differently, the data consistently showed that there was some enhancement in terms of sulphate reduction with the addition of ammonium and/or phosphate. In both MFT samples, methane production was inhibited for approximately the first 20 weeks, regardless of the amount of sulphate, ammonium, or phosphate that was added (Figure 3B,D).
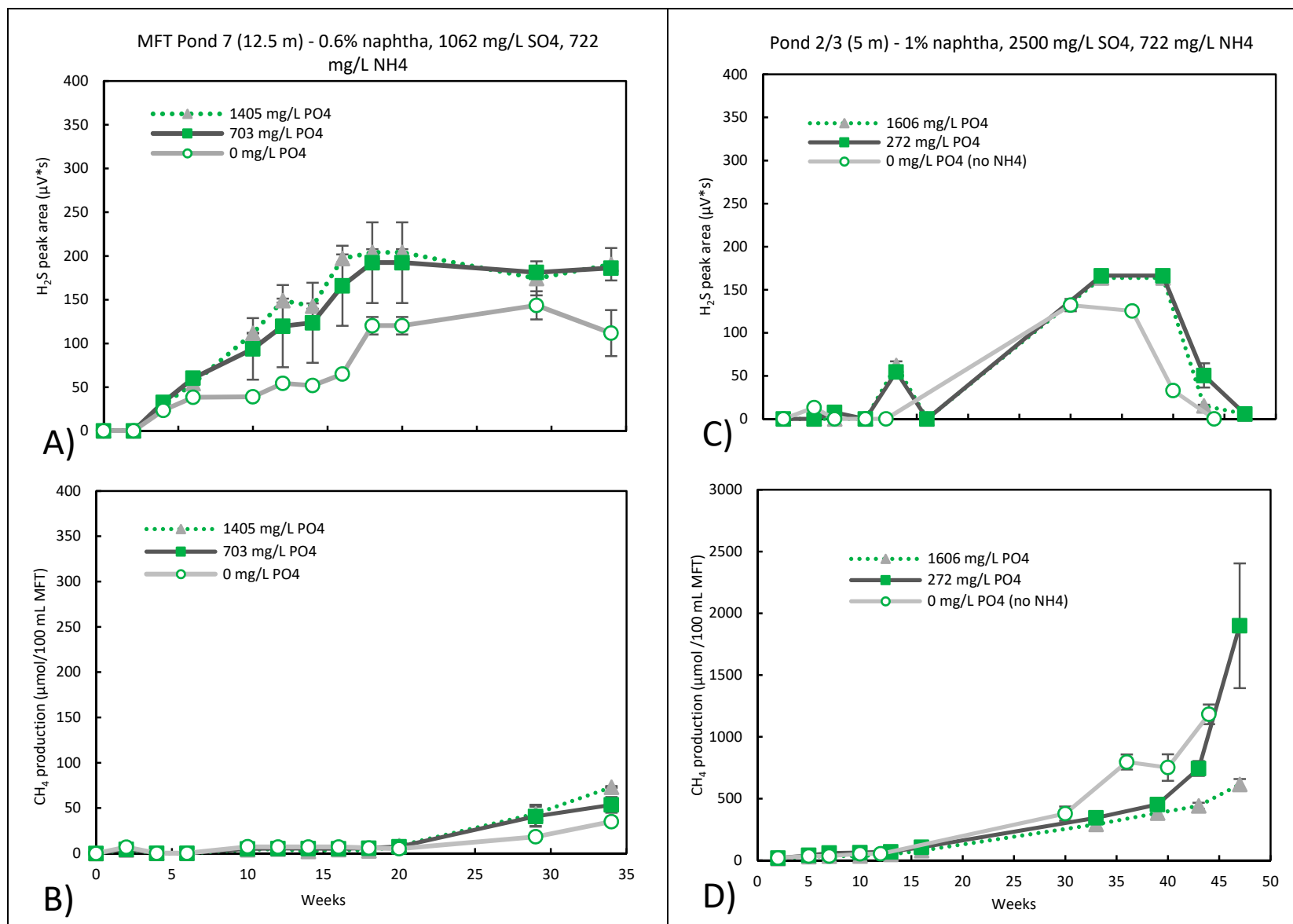

Figure 3. The effect of $\mathrm{NH}_{4}{ }^{+}$and $\mathrm{PO}_{4}{ }^{3-}$ on $(\mathbf{A}) \mathrm{H}_{2} \mathrm{~S}$ and (B) $\mathrm{CH}_{4}$ production by Pond 7 (12.5 m) MFT and (C) $\mathrm{H}_{2} \mathrm{~S}$ and (D) $\mathrm{CH}_{4}$ production by Pond 2/3 (5 m) under sulphate-reducing conditions. Measured sulphate concentrations in the pore waters of Pond 7 at week 0 was $\sim 645 \mathrm{mg} / \mathrm{L}$, which decreased to below detectable levels by week 34 . For Pond 2/3 (5 m) at week 0 , it was $\sim 1400 \mathrm{mg} / \mathrm{L}$, decreasing to $\sim 24 \mathrm{mg} / \mathrm{L}$ by week 13 , and was below detectable levels by week 44 . Microcosms were setup in duplicate, error bars were inserted, and where not visible, the error was too small to be seen.

There were a few notable differences in the results of the two pond samples. The $\mathrm{H}_{2} \mathrm{~S}$ produced in the Pond 7 microcosms persisted (Figure 3A), with methanogenesis slowly resuming at a low level around week 30-33 (Figure 3B). On the other hand, although $\mathrm{H}_{2} \mathrm{~S}$ was produced at a similar level in Pond 2/3 MFT (5 m), its disappearance began after 36-39 weeks of incubation (Figure 3C). Secondly, methanogenesis resumed at a higher rate in Pond 2/3 (5 m), even when $\mathrm{H}_{2} \mathrm{~S}$ levels were still high but increased even further as the $\mathrm{H}_{2} \mathrm{~S}$ disappeared (Figure 3D). Sulphate itself is not considered inhibitory to methanogens, but $\mathrm{H}_{2} \mathrm{~S}$ is [27]. This may explain why the resumption of methanogenesis was so much slower in Pond 7, in which $\mathrm{H}_{2} \mathrm{~S}$ persisted, compared to Pond 2/3 (5 m). The disappearance 
of $\mathrm{H}_{2} \mathrm{~S}$ from the Pond 2/3 microcosms could be due to abiotic and/or biotic processes. $\mathrm{H}_{2} \mathrm{~S}$ is very reactive and can react with metal ions to precipitate as metal sulphides. These black precipitates were not readily visible because the microcosm contents were obscured by bitumen. The chemical oxidation of $\mathrm{H}_{2} \mathrm{~S}$ with oxygen or nitrate may also occur [28], but there was no oxygen or nitrate present. Although some anaerobic, autotrophic archaea can oxidize $\mathrm{H}_{2} \mathrm{~S}$ with $\mathrm{CO}_{2}$ as the electron acceptor to obtain energy and support growth [29], $\mathrm{H}_{2} \mathrm{~S}$ removal was likely to be primarily abiotic [30].

\subsection{Nitrate Reduction}

The pore water of the as received MFT from Pond 7 at $12.5 \mathrm{~m}$ and Pond 2/3 at $5 \mathrm{~m}$ had no detectable levels of nitrate (Table 1). Similar to the studies under sulphatereducing conditions, either 0.6 or $1 \%$ (wt/vol) naphtha was added with ammonium and the increasing concentrations of phosphate. Methanogenesis was inhibited, and nitratereducing conditions were achieved by adding 584 and $1275 \mathrm{mg} / \mathrm{L}$ of $\mathrm{NO}_{3}{ }^{-}$to the MFT of Pond 7 and Pond 2/3 $(5 \mathrm{~m})$, respectively (Figure $4 \mathrm{~A}-\mathrm{D})$. Nitrate can be reduced through a series of intermediates (nitrate $\left(\mathrm{NO}_{3}{ }^{-}\right) \rightarrow$ nitrite $\left(\mathrm{NO}_{2}{ }^{-}\right) \rightarrow$ nitric oxide $\mathrm{NO} \rightarrow$ nitrous oxide $\mathrm{N}_{2} \mathrm{O} \rightarrow$ nitrogen gas $\left(\mathrm{N}_{2}\right)$ ) to nitrogen gas. Nitrate reduction was confirmed by the gas-phase evolution of $\mathrm{N}_{2} \mathrm{O}$, which was observed as early as day 2 with the Pond 7 MFT, with the amount of $\mathrm{N}_{2} \mathrm{O}$ produced increasing with the increasing phosphate.

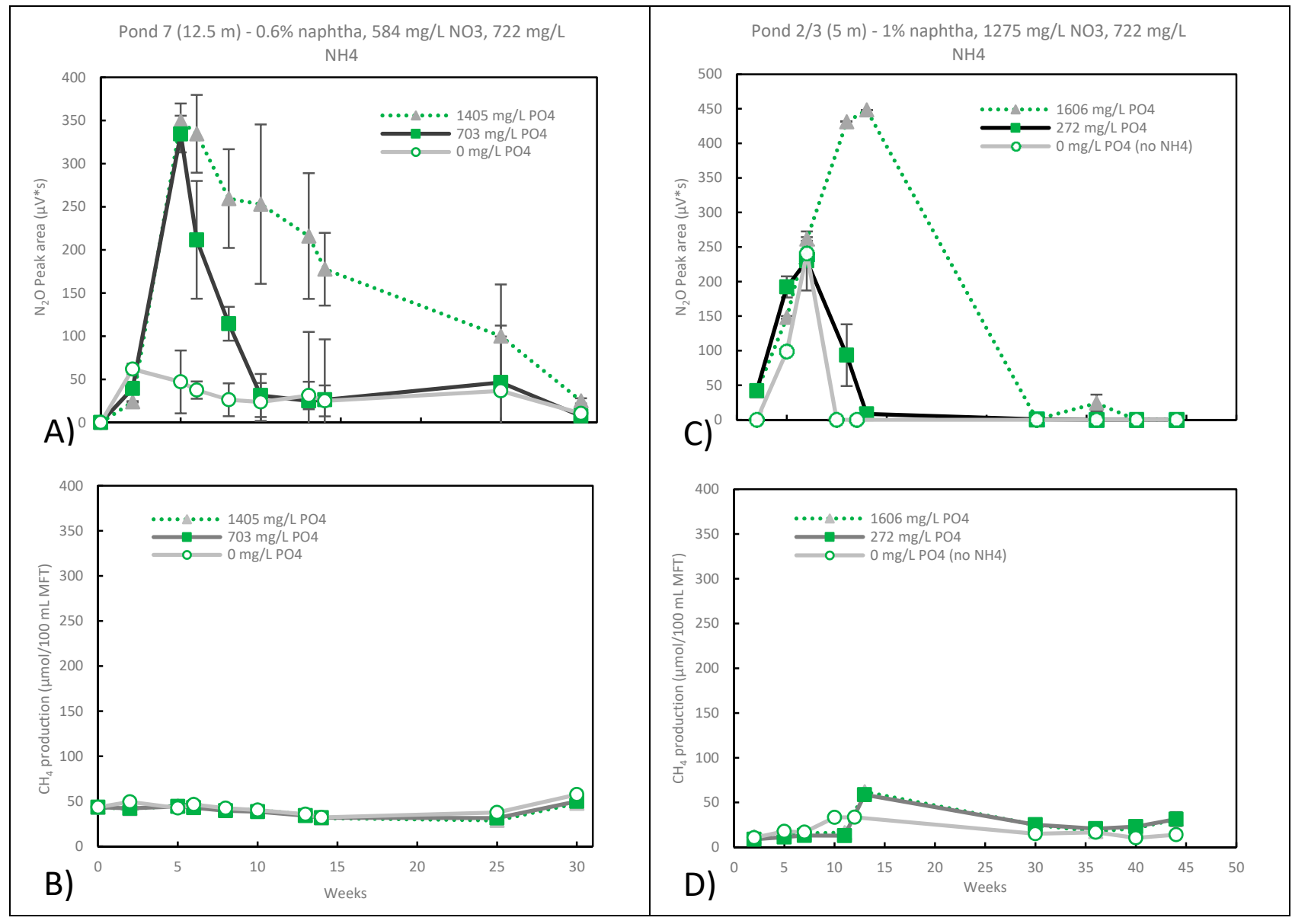

Figure 4. The effect of $\mathrm{NH}_{4}{ }^{+}$and $\mathrm{PO}_{4}{ }^{3-}$ on $(\mathbf{A}) \mathrm{N}_{2} \mathrm{O}$ and $(\mathbf{B}) \mathrm{CH}_{4}$ production by Pond 7 (12.5 m) MFT and (C) $\mathrm{N}_{2} \mathrm{O}$ and (D) $\mathrm{CH}_{4}$ production by Pond 2/3 (5 m) under nitrate-reducing conditions. Measured nitrate concentrations in the pore waters of Pond 7 at week 0 were $\sim 645 \mathrm{mg} / \mathrm{L}$, which decreased to below detectable levels by week 34 . For Pond 2/3 (5 m) at week 0 , they were $\sim 1400 \mathrm{mg} / \mathrm{L}$, decreasing to $\sim 24 \mathrm{mg} / \mathrm{L}$ by week 13 and were below detectable levels by week 44 . Microcosms were setup in duplicate, error bars were inserted, and where not visible, the error was too small to be seen. 
The addition of ammonium and phosphate was not required for nitrate reduction to occur in the Pond 2/3 (5 m) MFT (Figure 4C), and adding $722 \mathrm{mg} / \mathrm{L}$ ammonium and $272 \mathrm{mg} / \mathrm{L}$ phosphate resulted in a similar level of nitrate reduction. However, increasing the amount of phosphate $(1606 \mathrm{mg} / \mathrm{L})$ resulted in sustained $\mathrm{N}_{2} \mathrm{O}$ production over a longer period. Similar to Pond 2/3 $(5 \mathrm{~m})$, with the Pond $7 \mathrm{MFT}$, there was increasing nitrate-reducing activity $\mathrm{w}$ when the phosphate concentration increased (Figure $4 \mathrm{~A}$ ). $\mathrm{N}_{2} \mathrm{O}$ accumulation (Figure 4A,C) indicates a bottleneck at $\mathrm{N}_{2} \mathrm{O} \rightarrow \mathrm{N}_{2}$. However, the $\mathrm{N}_{2} \mathrm{O}$ reductase was active, and eventually, all of the $\mathrm{N}_{2} \mathrm{O}$ was reduced. This indicates that the $\mathrm{N}_{2} \mathrm{O}$ reductase had a low level of activity and/or its activity may have been inhibited by one or more $\mathrm{NO}_{\mathrm{x}}{ }^{-}$intermediates. $\mathrm{NO}_{2}{ }^{-}$has been frequently associated with $\mathrm{N}_{2} \mathrm{O}$ accumulation [31,32], and free nitrous acid $\left(\mathrm{HNO}_{2}\right)$ has also been linked to the inhibition of $\mathrm{N}_{2} \mathrm{O}$ reductase since inhibition depends on $\mathrm{pH}$ [33].

In both sets of microcosms, the $t=0$ nitrate levels were a little higher than the amount that was added, and by the final time point, the nitrate was at non-detectable levels. At an intermediate time point for Pond 2/3 (5 m) at week 13, the nitrate level was $\sim 24 \mathrm{mg} / \mathrm{L}$, decreasing from an initial value of $\sim 1400 \mathrm{mg} / \mathrm{L}$ for all samples. This was at the peak $\mathrm{N}_{2} \mathrm{O}$ at the highest phosphate concentration (Figure $4 \mathrm{C}$ ). Based on the rate of nitrate reduction in the first 13 weeks, it is likely that all of the nitrate was gone shortly after. However, methanogenesis continued to be inhibited from weeks 13 to 44 , when there was likely no nitrate and low $\mathrm{N}_{2} \mathrm{O}$ levels at the lower phosphate concentrations (Figure 4C). Other studies have shown that the products of nitrate reduction and not nitrate were more effective at inhibiting methanogenesis $[34,35]$. Nitrate had the weakest inhibition on methanogenesis by Methanosarcina barkeri and Methanobacterium bryantii, while $\mathrm{N}_{2} \mathrm{O}$ and $\mathrm{NO}_{2}{ }^{-}$had an intermediate effect, and NO had the strongest inhibition [34]. These inhibitions were found to be reversible or irreversible depending on the microorganism and the concentration of the inhibitor.

The release of $\mathrm{N}_{2} \mathrm{O}$ from tailing ponds is not desirable, as it is a more potent greenhouse gas than methane. Methane has a global warming potential (GWP) of 28-36 over the next 100 years, while the GWP of $\mathrm{N}_{2} \mathrm{O}$ has a global warming potential of 265-298 over the next 100 years [5]. In our studies, which were conducted in a closed environment, the $\mathrm{N}_{2} \mathrm{O}$ was eventually totally consumed and was reduced to nitrogen gas. The conditions that best inhibited methanogenesis and minimized $\mathrm{N}_{2} \mathrm{O}$ production would be the addition of nitrate without ammonium and/or phosphate (Figure $4 \mathrm{~A}, \mathrm{C}$ ).

Although there was some increasing microbial activity with increasing nutrient concentrations under nitrate- and sulphate-reducing conditions, this was not evident under methanogenic conditions. In this complex MFT environment, there are other factors that may also affect degradation rates, such as the poor bioavailability of naphtha. There was a significant amount of visible bitumen in all pond samples, with the most being observed in Pond 2/3 (5 m). It is likely that a majority of the naphtha partitioned into the residual bitumen, limiting naphtha's bioavailability [36] and hence its rate of biodegradation. In such a case, the naphtha degradation rate and hence its microbial activity would be limited either by the partitioning of naphtha into the aqueous phase where naphtha could be consumed by the naphtha-degraders [37] or by the hydrocarbon-degrading bacteria accessing naphtha by being in direct physical contact at the bitumen/aqueous phase interface $[37,38]$. Thus, even though ammonium and phosphate may be limiting, in the presence of bitumen, the bioavailability of naphtha is an even greater issue and may account for the results seen in Figure 1B. From the tested conditions, the addition of sulphate was also less effective at inhibiting methanogenesis than nitrate was. This may be related to the ease with which $\mathrm{H}_{2} \mathrm{~S}$ can be chemically removed via precipitation with metals.

\subsection{Potential Fate of Ammonium and Phosphate}

When concentrations of ammonium, phosphate, sulphate, or nitrate were prepared in just water, the measured aqueous concentration was close to the prepared concentrations and did not vary with time. However, after phosphate and/or ammonium were 
added to the MFT samples, the concentrations measured in the pore water recovered via centrifugation within $6 \mathrm{~h}$ of the experimental setup (i.e., "initial" concentrations) were much lower. For example, when 44.7 or $272 \mathrm{mg} / \mathrm{L}$ of phosphate was added, there was no detectable phosphate in the $\mathrm{t}=0$ samples, indicating a rapid loss. When $>272 \mathrm{mg} / \mathrm{L}$ of phosphate was added, the $t=0$ measurements ranged from $25-35 \%$ less than the amount added (Figure 5A). At low ammonium concentrations, there was almost total removal (e.g., $~ 80 \%$ loss at $57 \mathrm{mg} / \mathrm{L}$ ) and $30-45 \%$ loss at higher concentrations (Figure $5 \mathrm{~B}$ ). Similar ammonium losses were observed whether nitrate or sulphate were also present.

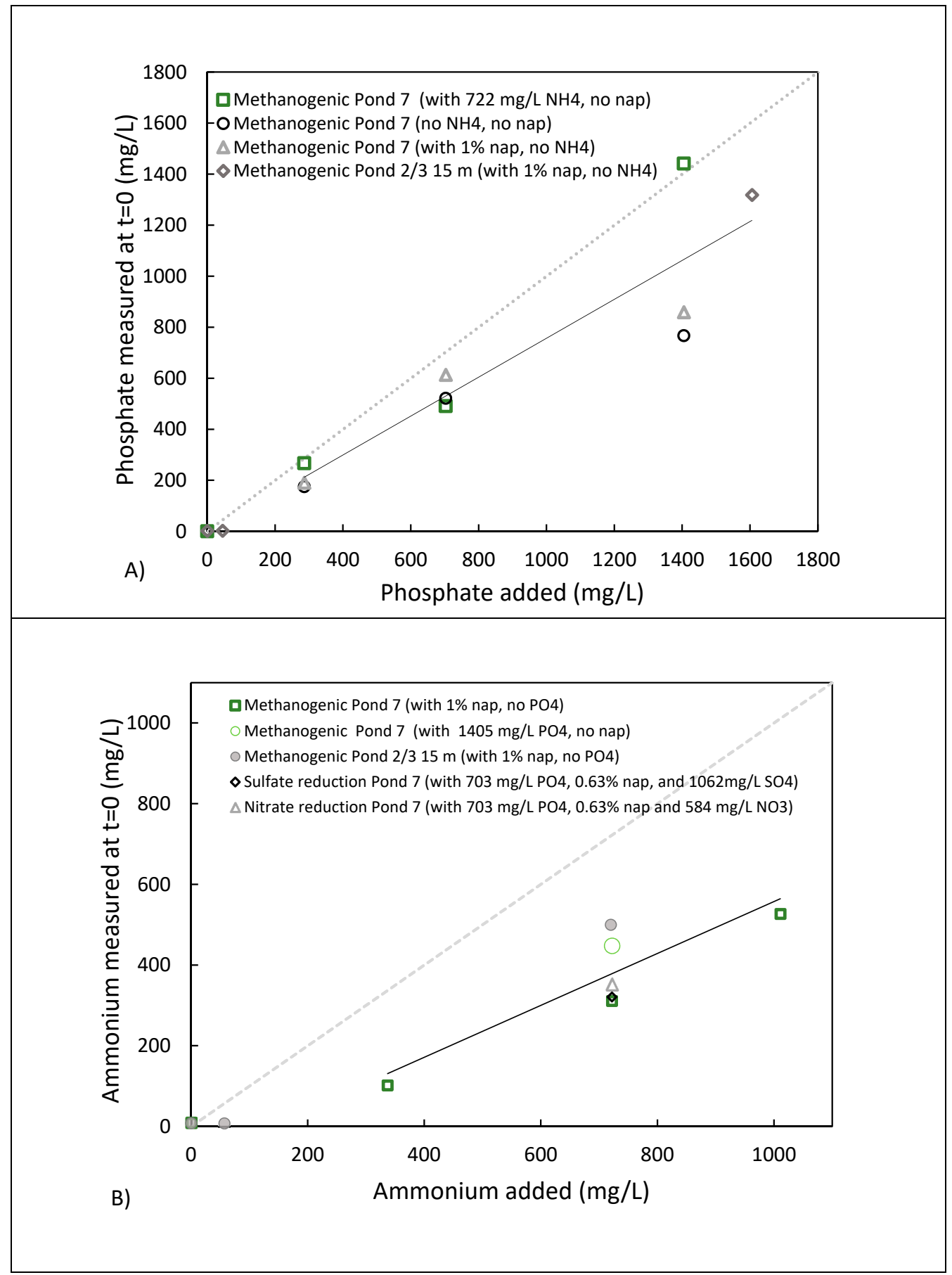

Figure 5. Plots showing the amount of (A) $\mathrm{PO}_{4}{ }^{3-}$ and (B) $\mathrm{NH}_{4}{ }^{+}$added to MFT samples and the "initial" concentration measured in the pore water. After phosphate and/or ammonium were added, the pore water was separated via centrifugation within a maximum of $6 \mathrm{~h}$ of experimental setup. 
This could explain why adding ammonium and phosphate did not affect methanogenesis at lower concentrations and only somewhat affected sulphate or nitrate reduction at the higher concentrations. It is also likely that the methanogens may not need ammonium, as it was recently reported that some methanogens may fix $\mathrm{N}_{2}$ in marine hyperthermophilic and thermophilic cultures [39], as determined in enrichment cultures from an Albian MFT [15] and in soils in the Florida Everglades [40]. However, further work is required to determine whether nitrogen-fixing methanogens are active in our studies. Higher ammonium concentrations may be inhibitory to some of these cultures and may have no effect on others [41].

The disappearance of phosphate and ammonium may be due to mineral precipitation or sorption onto the MFT matrix. To check for potential precipitates, after being mixed with ammonium and phosphate, the dried MFT solids were analyzed by X-ray diffraction. There was no evidence of precipitates such as struvite $\left(\mathrm{NH}_{4} \mathrm{MgPO}_{4} \cdot 6 \mathrm{H}_{2} \mathrm{O}\right)$, so if any precipitates were formed, they were below detectable levels.

The major mineral content of Pond 7 includes $27-31 \%$ quartz $\left(\mathrm{SiO}_{2}\right), 32-43 \%$ kaolinite $\left(\mathrm{Al}_{2} \mathrm{Si}_{2} \mathrm{O}_{5}(\mathrm{OH})_{4}\right), \sim 20 \%$ muscovite $\left((\mathrm{KF})_{2}\left(\mathrm{Al}_{2} \mathrm{O}_{2}\right)_{2}\left(\mathrm{SiO}_{2}\right)_{2}\right), 2-4 \%$ siderite $\left(\mathrm{FeCO}_{3}\right), 0.5-1.0 \%$ calcite $\left(\mathrm{CaCO}_{3}\right)$, and feldspars (Per. Comm. E. Hollander, Suncor) [4]. Many of these components have potential for sorption. The sorption of anions such as phosphate onto clays [42-48] has been extensively studied. While the sorption of cations such as ammonium onto clays [49,50] and either ammonium or phosphate onto quartz [51-53], muscovite [53], calcite [52,54], or iron minerals (e.g., geothitie) [43,48,55] have been demonstrated but have been less well studied. However, we were unable to find any published studies with MFT.

Clays such as kaolinite can sorb both cations and anions and have a higher cationic than anionic exchange capacity. This is reflected in the higher initial loss of $\mathrm{NH}_{4}^{+}$compared to $\mathrm{PO}_{4}{ }^{3-}$ (Figure 5). Cations such as $\mathrm{NH}_{4}{ }^{+}$can sorb via two mechanisms. One mechanism occurs via the permanent negative charge on the basal planes of the clay surface whereby the surface cations (e.g., $\mathrm{Al}^{3+}$ or $\mathrm{Si}^{4+}$ ) can be displaced by a species with a lower charge, e.g., $\mathrm{NH}_{4}{ }^{+}$, and hence does not depend on $\mathrm{pH}$ or ionic strength. However, the other mechanism depends on $\mathrm{pH}$ and ionic strength as the cations are sorbed to the surface by electrostatic interaction with the $\mathrm{OH}^{-}$groups arising from the deprotonation of the aluminol and silanol groups along the variable charged edges [56]. The pore water of the MFT contains high concentrations of competing cations (e.g., $\mathrm{Na}^{+}, \mathrm{K}^{+}$, and $\mathrm{Ca}^{2+}$ ) that have been shown to decrease the sorption of $\mathrm{NH}_{4}{ }^{+}$onto montmorillonite [57].

Anion adsorption occurs through the second mechanism and hence strongly depends on $\mathrm{pH}$. However, adsorption of $\mathrm{PO}_{4}{ }^{3-}$ is thought to be more complex and is thought to be linked to $\mathrm{Al}$ sites and may also involve multilayer adsorption (including penetration into the inter-lamellar spaces) and/or surface precipitation [42]. The latter is a very slow process that affects the aqueous concentration of phosphate after several days to weeks [42]. Thus, the rapid, early disappearance of ammonium and phosphate observed upon their addition to MFT is consistent with adsorption. Multilayer adsorption can occur at higher phosphate loadings as it moves into the inter-lamellar spaces and into amorphous regions of the clay surface [58]. While a significant amount of the MFT is kaolinite, there are other layered phyllosilicate minerals such as muscovite that comprise a substantial amount of the solids. The dominant charged groups in the feldspars are aluminol and silanol, which are also found in kaolinite and muscovite. These minerals have similar surface reactions in aqueous systems [59] and may be involved in the sorption of $\mathrm{NH}_{4}{ }^{+}$and $\mathrm{PO}_{4}{ }^{3-}$.

When Gerard (2016) [42] and Wei et al. (2014) [48] compared the binding of phosphate to a clayey (kaolinite) vs. sandy soil (i.e quartz silicates), they found that sorption onto a sandy soil was minor. For example, Gerard (2016) [42] calculated that a maximum of $15-50 \%$ phosphate would bind to a clayey soil compared to $0.5-3 \%$ in a sandy soil. Thus, in MFT, a much higher portion of anions that are similar to phosphate can be expected to bind to kaolinite compared to the quartz component.

Assuming that there were no other limitations, sorption onto the mineral components of MFT and non-detectable levels of phosphate in the pore water would ultimately lead to 
microbial activity being limited by the desorption equilibrium between nutrients sorbed on the mineral surface and the aqueous phase and their microbial utilization. Microbial activity in OSTPs appears to be controlled by multiple nutrient limitations. Apart from the terminal electron acceptor, it could include carbon, ammonium, and phosphate limitations.

\section{Conclusions}

The rate of methane production in unamended MFT samples correlated with the age of the sample such that it was the highest in the least dense (i.e., most recently discharged) MFT and was the lowest in the MFT sample that was most dense (i.e., the oldest). The addition of a carbon substrate increased methane production, but there was no correlation when the naphtha concentration was increased. Although non-detectable levels of phosphate and low ammonium indicated that these nutrients were potentially limiting microbial activity, their addition had no significant effect on methanogenesis but did somewhat enhance sulphate and nitrate reduction. This might be due to a combination of the loss of ammonium and phosphate via adsorption onto MFT minerals and the poor bioavailability of naphtha, which may have partitioned into the bitumen phase.

While both sulphate- and nitrate-reducing conditions inhibited methanogenesis, nitrate better sustained the inhibition for a longer duration. Under nitrate-reducing conditions, $\mathrm{N}_{2} \mathrm{O}$, a potent greenhouse gas was produced but was eventually consumed. Its production was the lowest without the addition of ammonium or phosphate and had a similar level of inhibition as when more $\mathrm{N}_{2} \mathrm{O}$ was produced. The lower effectiveness of sulphate to inhibit methanogenesis may be associated with a lower effectiveness of $\mathrm{H}_{2} \mathrm{~S}$ as an inhibitor compared to the $\mathrm{NO}_{x}{ }^{-}$intermediates and the ease by which $\mathrm{H}_{2} \mathrm{~S}$ can be abiotically removed. However, $\mathrm{N}_{2} \mathrm{O}$ is a potent greenhouse gas. We have demonstrated that multiple factors, such as the availability of carbon, nitrogen, and phosphorous substrates, simultaneously affect microbial activity in OSTPs.

Author Contributions: Conceptualization, J.A.R.; methodology, M.R.d.L.eS. and M.A.R.T.; investigation, M.R.d.L.eS., and M.A.R.T.; writing—original draft preparation, J.A.R., M.R.d.L.eS., and M.A.R.T.; writing-review and editing, J.A.R., M.R.d.L.eS., M.A.R.T., and B.A.R.; supervision, J.A.R. and B.A.R.; project administration, J.A.R.; funding acquisition, J.A.R. All authors have read and agreed to the published version of the manuscript.

Funding: This work was supported by funding from an NSERC Collaborative Research and Development Grant (CRDPJ 514706-17), Imperial Oil, Canada's Oil Sands Innovation Alliance (COSIA), and the Institute for Oil Sands Innovation (IOSI 2017-06) at the University of Alberta.

Institutional Review Board Statement: Not applicable.

Informed Consent Statement: Not applicable.

Data Availability Statement: The data presented in this study are available within the manuscript.

Acknowledgments: The authors would like to thank Suncor for providing the pond samples, invaluable technical support, and information on OSTPs as well as the Analytical Services at Queen's University for their technical and analytical support. The authors also acknowledge the technical assistance from Sreemoyee Ghosh Ray and Alison Holman in developing the experimental protocols and Stephanie Pfiffer for help with the literature.

Conflicts of Interest: The authors declare no conflict of interest.

\section{References}

1. Crude Oil Reserves. Available online: https://countryeconomy.com/energy-and-environmen/crude-oil/reserves (accessed on 8 September 2021).

2. IG. Available online: https://www.ig.com/en/trading-strategies/world-s-biggest-oil-producers-200722 (accessed on 8 September 2021).

3. CAPP. Available online: https://www.capp.ca/oil/what-are-the-oil-sands/ (accessed on 6 September 2021).

4. Suncor, E.H. Personal communication, August 2021. 
5. US EPA. Available online: https://www.epa.gov/ghgemissions/understanding-global-warming-potentials (accessed on 8 September 2021).

6. Fedorak, P.M.; Hrudey, S.E. The effects of phenol and some alkyl phenolics on batch anaerobic methanogenesis. Water Res. 1984, 18, 361-367. [CrossRef]

7. Fedorak, P.M.; Coy, D.L.; Salloum, M.J.; Dudas, M.J. Methanogenic potential of tailings samples from oil sands extraction plants. Can. J. Microbiol. 2002, 48, 21-33. [CrossRef] [PubMed]

8. Holowenko, F.M.; MacKinnon, M.D.; Fedorak, P.M. Methanogens and sulfate-reducing bacteria in oil sands fine tailings waste. Can. J. Microbiol. 2000, 46, 927-937. [CrossRef] [PubMed]

9. Siddique, T.; Fedorak, P.M.; Foght, J.M. Biodegradation of short-chain n-alkanes in oil sands tailings under methanogenic conditions. Environ. Sci. Technol. 2006, 40, 5459-5464. [CrossRef] [PubMed]

10. Siddique, T.; Fedorak, P.M.; MacKinnon, M.D.; Foght, J.M. Metabolism of BTEX and Naphtha Compounds to Methane in Oil Sands Tailings. Environ. Sci. Technol. 2007, 41, 2350-2356. [CrossRef]

11. Siddique, T.; Penner, T.; Semple, K.; Foght, J.M. Anaerobic biodegradation of longer-Chain $\mathrm{n}$-alkanes coupled to methane production in oil sands tailings. Environ. Sci. Technol. 2011, 45, 5892-5899. [CrossRef] [PubMed]

12. Siddique, T.; Penner, T.; Klassen, J.; Nesbø, C.; Foght, J.M. Microbial communities involved in methane production from hydrocarbons in oil sands tailings. Environ. Sci. Technol. 2012, 46, 9802-9810. [CrossRef]

13. Stasik, S.; Wendt-Potthoff, K. Interaction of microbial sulphate reduction and methanogenesis in oil sands tailings ponds. Chemosphere 2014, 103, 59-66. [CrossRef]

14. Shahimin, M.M.F.; Siddique, T. Methanogenic biodegradation of paraffinic solvent hydrocarbons in two different oil sands tailings. Sci. Total Environ. 2017, 583, 115-122. [CrossRef]

15. Collins, C.E.V.; Foght, J.M.; Siddique, T. Co-occurrence of methanogenesis and N2 fixation in oil sands tailings. Sci. Total Environ. 2016, 565, 306-312. [CrossRef] [PubMed]

16. Hungate, R.E. A roll tube method for cultivation of strict anaerobes. Method. Microbiol. 1969, 3B, 117-132.

17. APHA. Standard Methods for the Examination of Water, 22nd ed.; American Public Health Assn: Washington, DC, USA, 2012.

18. Symons, G.E.; Morey, B. The effect of drying time on the determination of solids in sewage and sewage sludges. Sewage Work J. 1941, 13, 936-939.

19. Colleran, E.; Pender, S.; Philpott, U.; O'Flaherty, V.; Leahy, B. Full-scale and laboratory-scale anaerobic treatment of citric acid production wastewater. Biodegradation 1998, 9, 233-245. [CrossRef] [PubMed]

20. Rinzema, A.; Lettinga, G. The effect of sulphide on the anaerobic degradation of propionate. Environ. Technol. Lett. 1988, 9, 83-88. [CrossRef]

21. Visser, A.; Nozhevnikova, A.N.; Lettinga, G. Sulphide inhibition of methanogenic activity at various pH levels at $55^{\circ} \mathrm{C} . J . \mathrm{Chem}$. Technol. Biotechnol. 1993, 57, 9-13. [CrossRef]

22. Siddique, T.; Semple, K.; Li, C.; Foght, J.M. Methanogenic biodegradation of iso-alkanes and cycloalkanes during long-term incubation with oil sands tailings. Environ. Pollut. 2020, 258, 113768. [CrossRef]

23. Small, C.C.; Cho, S.; Hashisho, Z.; Ulrich, A.C. Emissions from oil sands tailings ponds: Review of tailings pond parameters and emission estimates. J. Pet Sci. Eng. 2015, 127, 490-501. [CrossRef]

24. Colosimo, F.; Thomas, R.; Lloyd, J.R.; Taylor, K.G.; Boothman, C.; Smith, A.D.; Lord, R.; Kalin, R.M. Biogenic methane in shale gas and coal bed methane: A review of current knowledge and gaps. Int. J. Coal Geol. 2016, 165, 106-120. [CrossRef]

25. Laban, N.A.; Dao, A.; Semple, K.; Foght, J. Biodegradation of C7 and C8 iso-alkanes under methanogenic conditions: Methanogenic iso-alkane biodegradation. Environ. Microbiol. 2015, 17, 4898-4915. [CrossRef] [PubMed]

26. Takashima, M.; Speece, R.R. Mineral nutrient requirements for high-rate methane fermentation of acetate at low SRT. Res. J. Water Pollut. Control Fed. 1989, 61, 1645-1650.

27. Paulo, L.M.; Stams, A.J.M.; Sousa, D.Z. Methanogens, sulphate and heavy metals: A complex system. Rev. Environ. Sci. Biotechnol. 2015, 14, 537-553. [CrossRef]

28. Luther, G.W.; Findlay, A.J.; MacDonald, D.J.; Owings, S.M.; Hanson, T.E.; Beinart, R.A.; Girguis, P.R. Thermodynamics and kinetics of sulfide oxidation by oxygen: A look at inorganically controlled reactions and biologically mediated processes in the environment. Front. Microbiol. 2011, 2, 62. [CrossRef] [PubMed]

29. Berg, I.A.; Kockelkorn, D.; Ramos-Vera, W.H.; Say, R.F.; Zarzycki, J.; Hügler, M.; Alber, B.E.; Fuchs, G. Autotrophic carbon fixation in archaea. Nat. Rev. Microbiol. 2010, 8, 447-460. [CrossRef] [PubMed]

30. Ramos-Padrón, E.; Bordenave, S.; Linn, S.; Bhaskar, I.M.; Dong, X.; Sensen, C.W.; Fournier, J.; Voordouw, G.; Gieg, L.M. Carbon and sulfur cycling by microbial communities in a gypsum-treated oil sands tailings pond. Environ. Sci. Technol. 2011, 45, 439-446. [CrossRef]

31. Schulthess, R.; Kühni, M.; Gujer, W. Release of nitric and nitrous oxides from denitrifying activated sludge. Water Res. 1995, 29, 215-226. [CrossRef]

32. Betlach, M.R.; Tiedje, J.M. Kinetic explanation for accumulation of nitrite, nitric oxide, and nitrous oxide during bacterial denitrification. Appl. Environ. Microbiol. 1981, 42, 1074-1108. [CrossRef]

33. Zhou, Y.; Pijuan, M.; Zeng, R.J.; Yuan, Z. Free nitrous acid inhibition on nitrous oxide reduction by a denitrifying-enhanced biological phosphorus removal sludge. Environ. Sci. Technol. 2008, 42, 8260-8265. [CrossRef] [PubMed] 
34. Klüber, H.D.; Conrad, R. Inhibitory effects of nitrate, nitrite, $\mathrm{NO}$ and $\mathrm{N}_{2} \mathrm{O}$ on methanogenesis by Methanosarcina barkeri and Methanobacterium bryantii. FEMS Microbiol. Ecol. 1998, 25, 331-339. [CrossRef]

35. Banihani, Q.; Sierra-Alvarez, R.; Field, J.A. Nitrate and nitrite inhibition of methanogenesis during denitrification in granular biofilms and digested domestic sludges. Biodegradation 2009, 20, 801-812. [CrossRef]

36. Coulon, F.; Whelan, M.J.; Paton, G.I.; Semple, K.T.; Villa, R.; Pollard, S.J.T. Multimedia fate of petroleum hydrocarbons in the soil: Oil matrix of constructed biopiles. Chemosphere 2010, 81, 1454-1462. [CrossRef] [PubMed]

37. Alexander, M. Biodegradation and Bioremediation; Academic Press: New York, NY, USA, 1994; pp. 138-139.

38. Stroud, J.L.; Paton, G.I.; Semple, K.T. Microbe-aliphatic hydrocarbon interactions in soil: Implications for biodegradation and bioremediation. J. Appl. Microbiol. 2007, 102, 1239-1253. [CrossRef]

39. Nishizawa, M.; Miyazaki, J.; Makabe, A.; Koba, K.; Takai, K. Physiological and isotopic characteristics of nitrogen fixation by hyperthermophilic methanogens: Key insights into nitrogen anabolism of the microbial communities in Archean hydrothermal systems. Geochim. Cosmochim. Acta 2014, 138, 117-135. [CrossRef]

40. Bae, H.-S.; Morrison, E.; Chanton, J.P.; Ogram, A. Methanogens are major contributors to nitrogen fixation in soils of the Florida Everglades. Appl. Environ. Microbiol. 2018, 84, e02222-17. [CrossRef] [PubMed]

41. Offre, P.; Spang, A.; Schleper, C. Archaea in Biogeochemical Cycles. Annu. Rev. Microbiol. 2013, 67, 437-457. [CrossRef] [PubMed]

42. Gérard, F. Clay minerals, iron/aluminum oxides, and their contribution to. Geoderma 2016, 262, 213-226. [CrossRef]

43. Gimsing, A.L.; Borggaard, O.K. Competitive adsorption and desorption of glyphosate and phosphate on clay silicates and oxides. Clay Miner. 2002, 37, 509-515. [CrossRef]

44. Edzwald, J.K.; Toensing, D.C.; Leung, M.C.-Y.Y. Phosphate adsorption reactions with clay minerals. Environ. Sci. Technol. 1976, 10, 485-490. [CrossRef]

45. He, L.M.; Zelazny, L.W.; Baligar, V.C.; Ritchey, K.D.; Martens, D.C. Ionic Strength Effects on Sulfate and Phosphate Adsorption on $\gamma$-Alumina and Kaolinite: Triple-Layer Model. Soil Sci. Soc. Am. J. 1997, 61, 784-793. [CrossRef]

46. Moharami, S.; Jalali, M. Removal of phosphorus from aqueous solution by Iranian natural. Chem. Eng. J. 2013, 223, 328-339. [CrossRef]

47. Ioannou, A.; Dimirkou, A. Phosphate adsorption on hematite, kaolinite, and kaolinite-hematite. J. Colloid Interface Sci. 1997, 192, 119-128. [CrossRef] [PubMed]

48. Wei, S.; Tan, W.; Liu, F.; Zhao, W.; Weng, L. Surface properties and phosphate adsorption of binary systems containing goethite and kaolinite. Geoderma 2014, 213, 478-484. [CrossRef]

49. El-Shafey, O.I.; Fathy, N.A.; El-Nabarawy, T.A. Sorption of ammonium ions onto natural and modified Egyptian kaolinites: Kinetic and equilibrium studies. Adv. Phys. Chem. 2014, 935854. [CrossRef]

50. Alshameri, A.; He, H.; Zhu, J.; Xi, Y.; Zhu, R.; Ma, L.; Tao, Q. Adsorption of ammonium by different natural clay minerals: Characterization, kinetics, and adsorption isotherms. Appl. Clay Sci. 2018, 159, 83-93. [CrossRef]

51. Jiang, C.; Jia, L.; Zhang, B.; He, Y.; Kirumba, G. Comparison of quartz sand, anthracite, shale and biological ceramsite for adsorptive removal of phosphorus from aqueous solution. J. Environ. Sci. 2014, 26, 466-477. [CrossRef]

52. Reddy, K.R.; Xie, T.; Dastgheibi, S. Nutrients removal from urban stormwater by different filter materials. Water Air Soil Pollut. 2014, 225, 1778. [CrossRef]

53. Perrott, K.W.; Langdon, A.G.; Wilson, A.T. Sorption of anions by the cation exchange surface of muscovite. J. Colloid Interface Sci. 1974, 48, 10-19. [CrossRef]

54. Freeman, J.S.; Rowell, D.L. The adsorption and precipitation of phosphate onto calcite. J. Soil Sci. 1981, 32, 75-84. [CrossRef]

55. Geelhoed, J.S.; Hiemstra, T.; Van Riemsdijk, W.H. Phosphate and sulfate adsorption on goethite: Single anion and competitive adsorption. Geochim. Cosmochim. Acta 1997, 61, 2389-2396. [CrossRef]

56. Lazaratou, C.; Lazaratou, C.V.; Vayenas, D.V.; Papoulis, D. The role of clays, clay minerals and clay-based materials for nitrate removal from water systems: A review. Appl. Clay Sci. 2020, 185, 105377. [CrossRef]

57. Mazloomi, F.; Jalali, M. Adsorption of ammonium from simulated wastewater by montmorillonite nanoclay and natural vermicullite: Experimental study and simulation. Environ. Monitor Assess. 2017, 189, 415. [CrossRef] [PubMed]

58. Muljadi, D.; Posner, A.M.; Quirk, J.P. The mechanism of phosphate adsorption by kaolinite, gibbsite, and pseudoboehmite. Part II. The location of adsorption sites. Eur. J. Soil Sci. 1966, 17, 230-237. [CrossRef]

59. Farquhar, M.L.; Vaughan, D.J.; Hughes, C.R.; Charnock, J.M.; England, K.E.R. Experimental studies of the interaction of aqueous metal cations with mineral substrates: Lead, cadmium, and copper with perthitic feldspar, muscovite, and biotite. Geochim. Cosmochim. Acta 1997, 61, 3051-3064. [CrossRef] 